\title{
Localization of Sulfated Polysaccharides into the Physodes of the alga Padina gymnospora and their Relation to Heavy Metal Accumulation and Cell Wall
} Formation

\author{
L.T. Salgado, ${ }^{1}$; L.R.Andrade ${ }^{1}$, and G.M. Amado Filho ${ }^{2}$
}

1. Laboratório de Biomineralização, ICB/CCS, Universidade Federal do Rio de Janeiro, Cidade Universitária, 21941-590, Rio de Janeiro, RJ, Brasil. 2. Prog. Zona Costeira, Instituto de Pesquisas Jardim Botânico/MMA, Rua Pacheco Leão 915, 22460-030, Rio de Janeiro, RJ, Brasil. E-mail: gfilho@jbrj.gov.br

The brown alga Padina gymnospora has been intensively studied due the chemical properties of cell wall polysaccharides (fucans and alginates), that are responsible for the high capability in heavy metal accumulation. Recently, intracellular vesicles named physodes have been associated to the processes of heavy metal accumulation and cell wall formation [1,2]. The composition of these organelles is not restricted to the presence of phenolic compounds, and polysaccharides can be present [2]. In the brown alga Fucus distichus, alginate (carboxylic polysaccharides that strongly bind calcium) was detected by immunocytochemistry [2]. The physodes are naturally exuded into the cell walls and can contribute to deposition of wall components. Until now, the fucans (sulfated polysaccharides) had not been detected inside these organelles. The aim of this work was to verify the presence of fucans into physodes, and determine the elemental composition of physodes from algae collected in a heavy metal contaminated area, by using hystochemical and cytochemical analysis with lectins, and X-ray microanalysis.

The lectins Ulex europaeus (UEA) specific to $\alpha$-L-fucose, and Concanavalin A (ConA) specific to terminal residues of $\alpha$-D-mannosyl and $\alpha$-D-glucosyl were used to localize fucans in P. gymnospora physodes [3]. Hystochemical tests were performed with lectins conjugated with FITC for fluorescence light microscopy, and colloidal gold particles for TEM observations. Energy Dispersive X-ray Analysis (EDXA) associated to TEM was used to determine the elemental composition of Padina gymnospora physodes collected in Sepetiba Bay, a heavy metal contaminated area in Rio de Janeiro State. A TEM Jeol 1200 EX equipped with a Noran-Voyager analytical system was used.

The results obtained were: an intense labeling with UEA in cell walls and physodes (Figures 1-2); a discreet labeling with ConA in physodes (Figure 3); and the detection of $\mathrm{Zn}$ and $\mathrm{S}$ as main elements (Figure 4).

The detection of $\mathrm{Zn}$ indicates that physodes of Padina gymnospora can absorb heavy metals from seawater. The detection of $\mathrm{S}$, in addition to the localization of the monosaccharides fucose, mannose and glucose into physodes, confirm the presence of fucans in these organelles. We concluded that the fucans into the physodes are related to the cell walls formation and can be related to the heavy metal accumulation process in $P$. gymnospora.

\section{References}

[1] C.S. Karez and R.C.Pereira, Botanica Marina 38 (1995) 151.

[2] M. Shoenwaelder, Phycological Reviews 21. Phycologia 41 (2) (2002) 125.

[3] L.R. Andrade, et al., (submitted).

[4] Financial Support: CNPq, FAPERJ, COPEA/UFRJ, Institutos do Milênio/CNPq. 

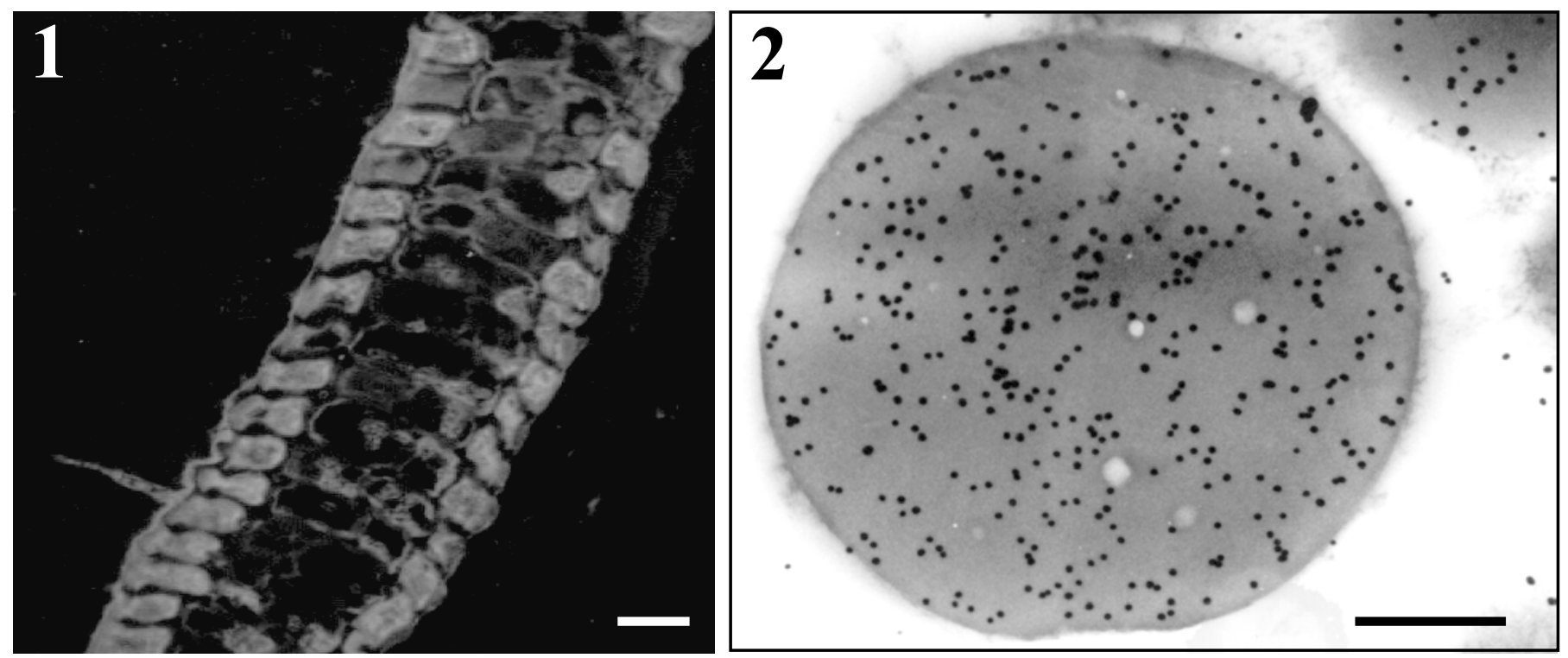

Figure 1: Fluorescence microscopy image of Padina gymnospora (cross section) showing the intense labeling of the lectin Ulex europaeus in physodes and cell walls $($ Bar $=50 \mu \mathrm{m})$. Figure 2: Transmission electron micrograph of P. gymnospora physodes showing intense labeling by Ulex europaeus colloidalgoldconjugates $(\mathrm{Bar}=0.7 \mu \mathrm{m})$.
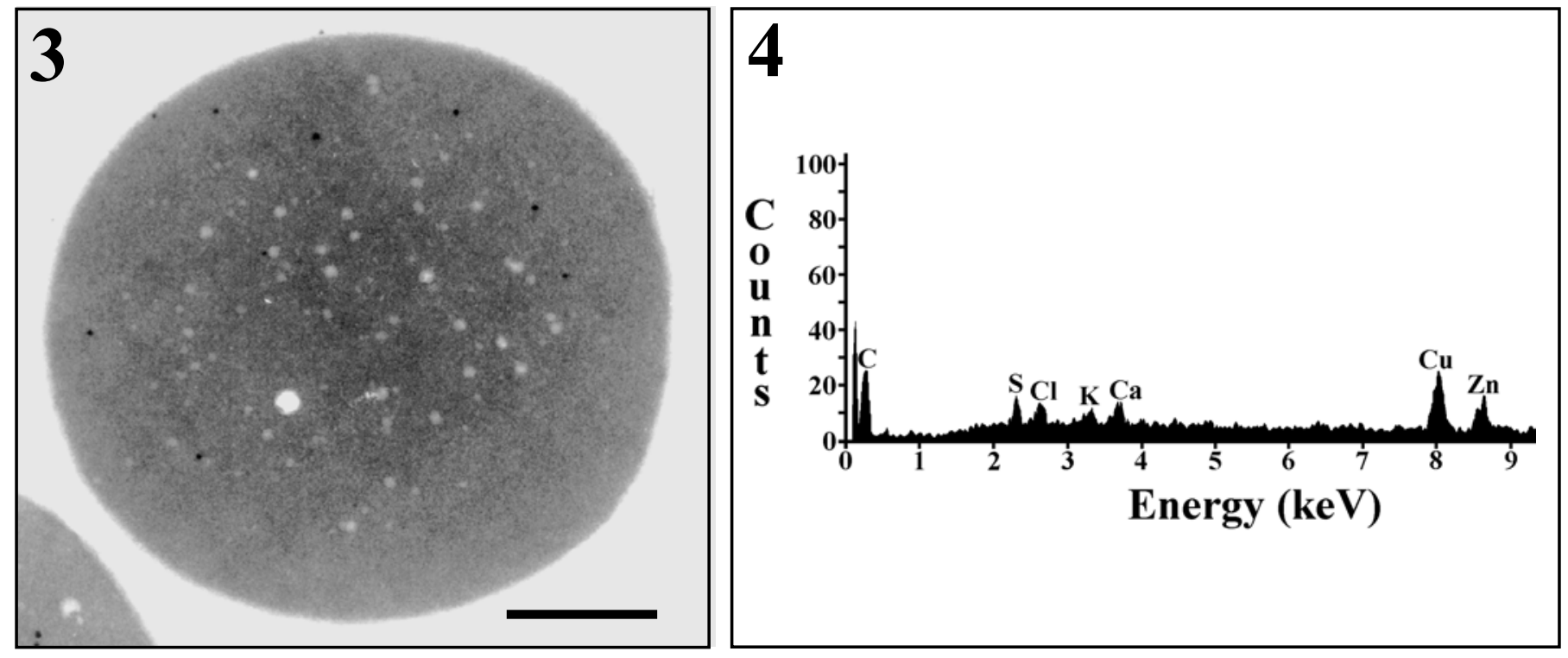

Figure 3: Transmission electron micrograph of $P$. gymnospora physodes labeled with the lectin Concanavalin A $(\mathrm{Bar}=1 \mu \mathrm{m})$. Note the presence of few gold particles (dark dots). Figure 4: Energy dispersive X-rays analysis spectrum of $P$. gymnospora physode collected in a heavy metal contaminated area, showing the presence of $\mathrm{S}$ and $\mathrm{Zn}$ associated with $\mathrm{C}, \mathrm{Cl}, \mathrm{K}$ and $\mathrm{Ca}$. $\mathrm{Cu}$ comes from the grid bar. 